\title{
H.M. The King's Royally Initiated LERD Project on Community Wastewater Treatment through Small Wetlands and Oxidation Pond in Phetchaburi, Thailand
}

\author{
Kasem Chunkao ${ }^{1,2}$, Wit Tarnchalanukit ${ }^{1,2}$, Paiboon Prabuddham ${ }^{1,2}$, Onanong Phewnil ${ }^{1,2}$, Surat Bualert ${ }^{1}$, Kittichai \\ Duangmal $^{1}$, Thanit Pattamapitoon ${ }^{1,2}$ \& Chatri Nimpee ${ }^{1}$ \\ ${ }^{1}$ Department of Environmental Science, Faculty of Environment, Kasetsart University, Bangkok, 10900, Thailand \\ ${ }^{2}$ The King's Royally Initiated Laem Phak Bia Environmental Research and Development Project, Ban Laem \\ District, Phetchaburi Province, Chaipattana Foundation, 76100, Thailand \\ Correspondence: Kasem Chunkao, The King's Royally Initiated Laem Phak Bia Environmental Research and \\ Development Project, Phetchaburi Province 76100, Thailand \& Department of Environmental Science, Faculty of \\ Environment, Kasetsart University, Bangkok 10900, Thailand. E-mail: prof.kasemc@gmail.com
}

Received: May 23, $2014 \quad$ Accepted: June 18, $2014 \quad$ Online Published: September 26, 2014

doi:10.5539/mas.v8n5p233 URL: http://dx.doi.org/10.5539/mas.v8n5p233

\begin{abstract}
The research on community wastewater treatment through small aquatic-planting and grass-filtration constructed wetland in cooperating with oxidation ponds is aimed to establish demonstration models for eliminating organic contaminants under nature-by-nature process, simple technology and less expenses. There have been 7 small wetlands on $100-\mathrm{m} \times 5-\mathrm{m} \times 0.75-\mathrm{m}$ small vertical flow construction wetlands (VFCW), 7 small wetlands on $25-\mathrm{m} \times 5-\mathrm{m} \times 0.75-\mathrm{m}$ small VFCW in cooperating with zero discharge, 2 experimental plots of planted mangrove forest and 5 -consecutive oxidation ponds plus 3 herbivore fishes per square meter.

For research operation, some municipal wastewater were pumped about $0.025-\mathrm{cms}$ flow rate from Phetchaburi collected pond through 18.5-km HPDE pipe with separating receivers: firstly, to small grass and aquatic planted wetlands; secondly, to small constructed wetlands; thirdly, to the planted mangrove forest; and finally to the 5-consecutive ponds in descending order of $20 \mathrm{~cm}$ by beginning the depth of $2.6 \mathrm{~m}$ at the first pond (sedimentation pond) till $1.8 \mathrm{~m}$ at the last pond, In basic principles, an influent has to flow continuously at height of one-third depth below surface of oxidation pond on hydraulic retention time (HRT), then flowing over weir crest about $5 \mathrm{~cm}$. The effluent of each oxidation pond was monthly sampled for analyzing the water quality in order to estimate the efficiency of wastewater treatment. In the same procedures, the effluent from small wetlands as grown by aquatic plants as well as zero discharge had to collect for water quality analysis. The results found the wastewater treatment efficiency above 60 percentages for COD, BOD, and TSS. The usable life of plants for maximum wastewater treatment efficiency were specified at 90 days and 45 days for aquatic plants (Typha angustifolia Linn. and Cyperus corymbosus Rottb.), respectively. It was noticed that small wetland and oxidation pond were suitable for community wastewater treatment and gained benefits from the wastewater treatment system.
\end{abstract}

Keywords: community, wastewater treatment, small wetlands, oxidation ponds

\section{Introduction}

It has been wondered why various types of obligatory engineering-device installation for wastewater treatment from municipals, industrial factories, hotels and livestock farms but polluted water is still expanded to every river, stream, canal, lake, reservoir and wetland. In other words, the failure of engineering tools cannot be specified what is the grassroots of problem. It might be just installed the wastewater treatment devices but they were ignored to operate because of economizing the capital, no plan for monitoring, directly smuggling wastewater to public water sources and no employment of environmental technologists. Moreover, Thai traditional human settlement along both riverbanks would be another cause to pollute community wastewater to stream water as the same as livestock-farm behaviors. This is why stream pollution gradual increasing day by day without stopping the situation.

H.M. King Bhumibol has realized how big problems of seriously stream pollution around the country, and 
initiated the Royal Laem Phak Bia Environmental Research and Development Project (Royal LERD) with applying the nature-by-nature processes at Laem Phak Bia Sub-District, Ban Laem District, Phetchaburi Province, Thailand in order to find simplicity technology and probable utilization of local materials or the cheapest expenses for encouraging the community wastewater treatment before draining into the streams. Under stated condition, small wetland and oxidation pond could be the most probable technologies for wastewater treatment from households, villages, communities and municipals. These technologies can be applied to high organic waste concentration, i.e. livestock farms, agro-industrial factories and slaughterhouses as well as industrial factories but pretreatment needs before or after draining wastewater or treated wastewater into the small wetlands and/or oxidation ponds which utilizing nature-by-nature processes.

Theoretically, the nature-by-nature processes are implied as photosynthesis, thermo-siphon and thermo-osmosis processes for supporting naturally bacterial digestion of organic waste as the contaminants in wastewater from any point sources. This could be expected to serve need of the Royal LERD project to take small wetland and oxidation pond for disseminating the know-how on wastewater treatment to the concerned point sources around the country.

\section{Material and Methods}

\subsection{Location of the Royal LERD Project}

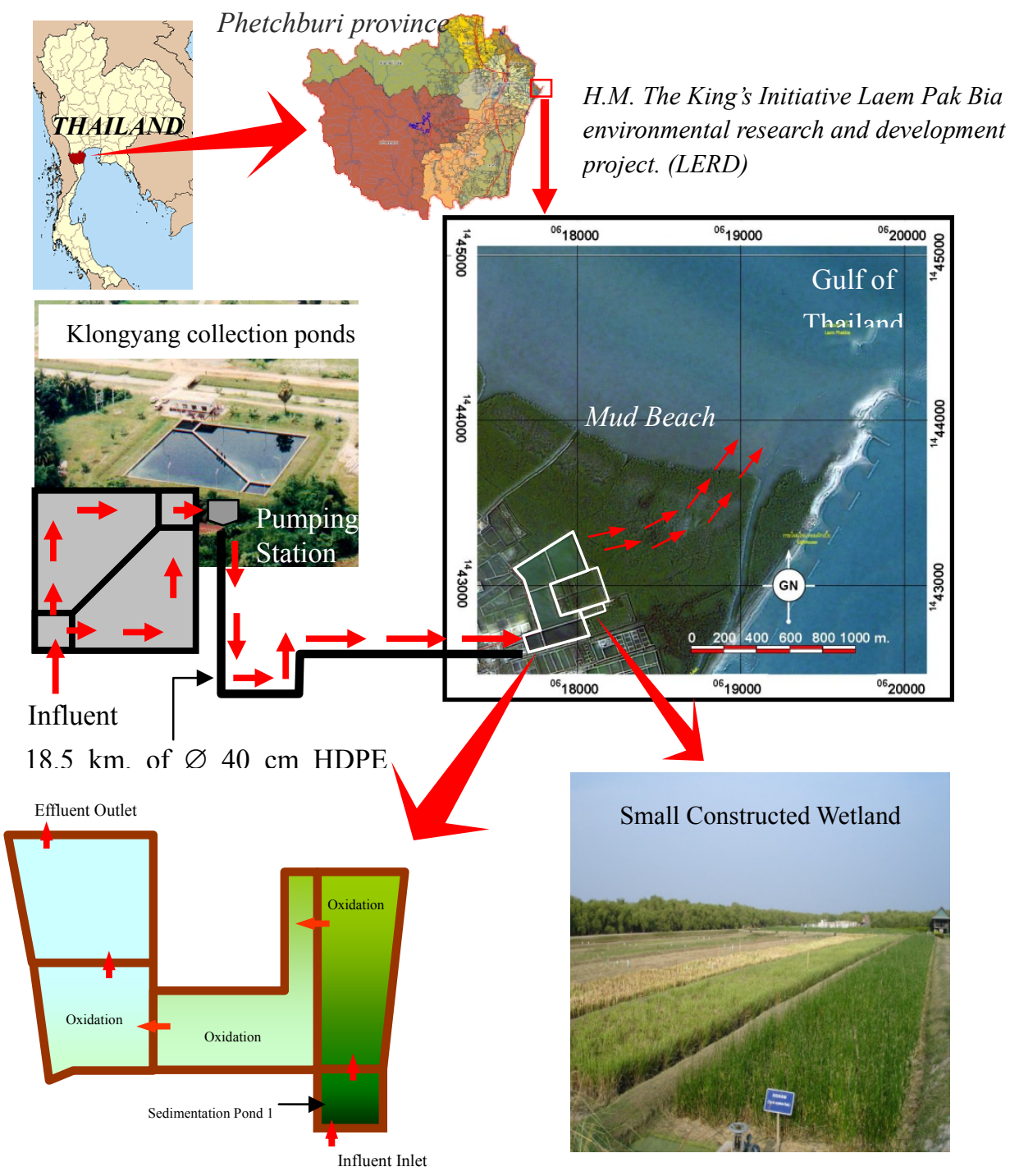

Figure 1. Location of Phetchaburi municipal and the Royal LERD project site at Laem Phak Bia Sub-District, Ban Laem District, Phetchaburi Province 
Phetchaburi drainage area is only one system among more 25 rivers in Thailand that composing of one river (Phetchaburi river) to transfer streamflow directly from headwater to the river mouth through five large communities and passing to municipal as a main city before taking the organic pollutants and toxicants to the Gulf of Thailand. For eliminating organic-toxicant wastes in Phetchaburi river, the Royal LERD project has been taken place for decreasing wastewater from fresh-food markets, local sweetmeat factories, municipal sewage, livestock farms, agro-industrial factories and households along the riverbanks by transferring $18.5-\mathrm{km}$ HPDE pipes to the project site at Laem Phak Bia village as seen in Figure1.

Wastewater from the above point sources flowed through municipal sewerage to four pumping stations which connect to Klongyang collection ponds. Then, wastewater was pumped through 18.5-km HPDE pipes to drain out to two lines: one to small wetlands; and the other to 5-consecutive ponds (Figure 1).

\subsection{Small Constructed Wetlands}

Small constructed wetlands were made in size of 100-m length, 5-m width and 1-m depth which furnished on each three 300-m-hole pipe in parallel to the bottom in order to allow treated wastewater flowing through outlet. Then after, gravel pavement was performed at about 10-cm depth, another 10-cm soil overtopping, following with $30-\mathrm{cm}$ sandy soils (paddy soil: sand ratio equivalent to $3: 1$ ) for growing aquatic plants, and final $30-\mathrm{cm}$ height for wastewater level which flow vertically through soils, sand, and gravel until running out from outlet.

In accordance with research objectives, the small vertical flow constructed wetlands (small VFCW) was divided into four $20-\mathrm{m}$ sections. Each section composed of three $10-\mathrm{cm}$ polyethylene pipes at every section in order to take the vertical flow of treated wastewater to analyze water quality as shown in Figure 2.

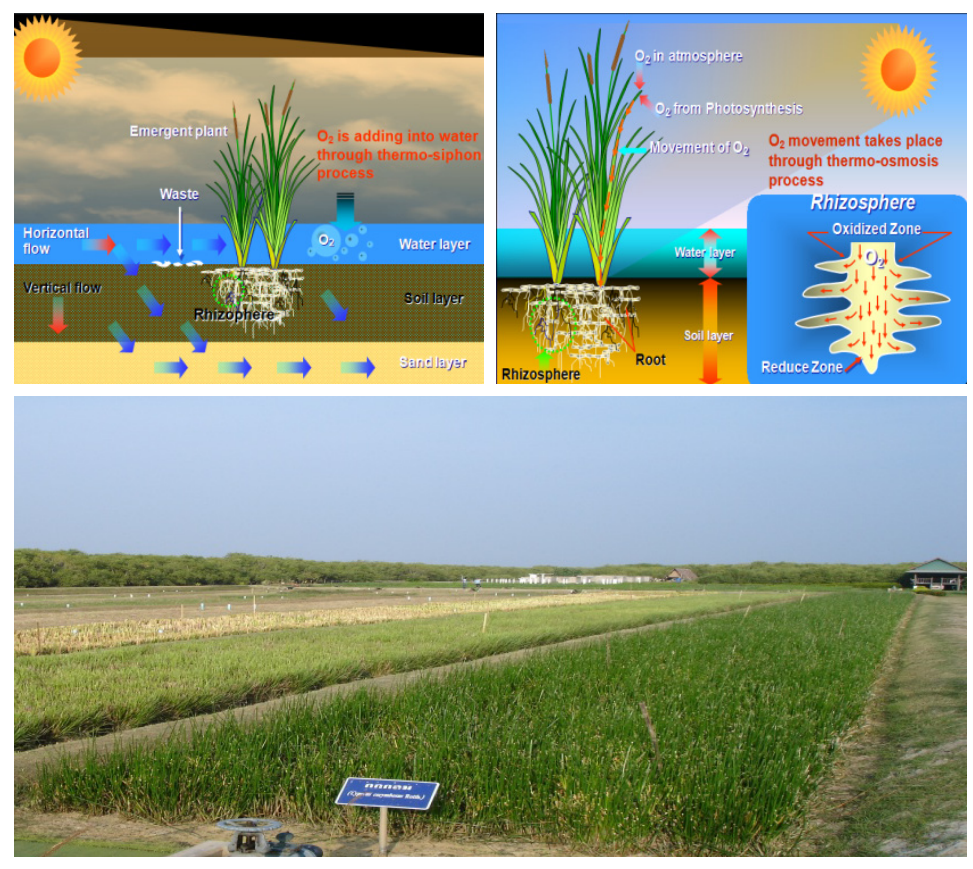

Figure 2. Hypothetical vertical flow constructed wetlands (5 x 100-m surface area and 1-m depth) and filling sandy soils (ratio of paddy soils to sand Is equivalent to 3:1) for growing Typha angustifolia Linn. and Cyperus corymbosus Rottb. as used for community wastewater treatment at the Royal LERD project site

\subsection{Five-Consecutive Oxidation Ponds}

Construct the consecutive oxidation ponds 1, 2, 3, 4 and 5 with the depth of them about 3, 2.7, 2.5, 2.3, and 2.1 meters, respectively. Then wastewater was flown at the level of $20-\mathrm{cm}$ difference by setting the water depth at 2.7, 2.5, 2.3, 2.1, and 1.9 meters of ponds $1,2,3,4$, and 5, equivalent to 75 percent of pond volume. (Figure 1). Finally, continuity flow from Klongyang collection pond about 3,600 cubic meters per day was pumped through 18.5-km HPDE pipes, diverting some part into constructed wetland at setting depth of $30 \mathrm{~cm}$ above water surface for 5-day stagnating and 2 days releasing. The other part was flown into 5-consecutive ponds for gradually decreasing the organic waste in wastewater by bacterial digesting process. 


\subsection{Samples Analysis}

Wastewater samples in terms of influent and effluent were collected every ten days, since the year of 2000, for analyzing the water quality indexes, i.e. COD, BOD, TDS, TSS, EC, pH, temperature, salinity, NPK, some heavy metals. At the same time, height measurement of Typha and Cyperus were conducted until the growth rate equivalent to zero which is the period ( 90 days of age) of maximum treatment efficiency. Typha and Cyperus were harvested at age of 90 days for determining the biomass and also to analyze plat nutrients and some heavy metals. Moreover, soil samples were taken before the experiment and after harvesting for analysis of plant nutrients and some heavy metals.

\section{Results and Discussion}

Owning to the Royal LERD project on community wastewater treatment has been launched since 1993 and beginning to collect the samples in the year of 2000 in every ten days for the first 5 years and monthly period after the year of 2003. The better illustration of analyzed data for this study were taken in account with representative climate and wastewater quality will be presented in the following sections.

\subsection{Biomass and Accumulative Plant Nutrients}

Due to Typha and Cyperus were planted in the 5-m x 100-m vertical flow constructed wetlands (VFCW) with $35-\mathrm{cm}$ spacing with about $25-\mathrm{cm}$ depth of growing materials (paddy soil-sand ratio is equivalent to $3: 1$ ), the measurement of height growth was taken in every seven days as shown in Table 1 and Figure 3 . The indicated that average growth rate was more or less zero when their ages reached at about 90 days and 45 days for useful life of Typha and Cyperus, respectively. The aforesaid statement presented that Typha and Cyperus grew well in Phetchaburi municipal wastewater and also the maximum effective treatment in constructed wetland concept., although Typha was high evapotranspiration rate (Pedescoll et al., 2013; Phewnil et al., 2014)

Table 1. Height growth and biomass of Typha angustifolia Linn. and Cyperus corymbosus Rottb. as used for community wastewater treatment at the Royal LERD project site in Phetchaburi province Thailand

\begin{tabular}{ccc}
\hline \multirow{2}{*}{ Plant age (days) } & \multicolumn{2}{c}{ Height growth $(\mathrm{cm})}$. \\
\cline { 2 - 3 } & Typha angustifolia Linn. & Cyperus corymbosus Rottb. $^{\mathrm{a}}$ \\
21 & $96.1^{\mathrm{a}}$ & $120.9^{\mathrm{b}}$ \\
28 & $137.3^{\mathrm{b}}$ & $162.1^{\mathrm{c}}$ \\
42 & $168.5^{\mathrm{c}}$ & $165.1^{\mathrm{d}}$ \\
50 & $184.9^{\mathrm{d}}$ & - \\
64 & $216.0^{\mathrm{e}}$ & - \\
70 & $239.5^{\mathrm{f}}$ & - \\
84 & $241.0^{\mathrm{f}}$ & 0.30 \\
\hline \multirow{2}{*}{ Biomass: dry weight $\left(\mathrm{kg} / \mathrm{m}^{3}\right)$} & $316.0^{\mathrm{g}}$ & $(55$ cut off $)$ \\
\hline
\end{tabular}

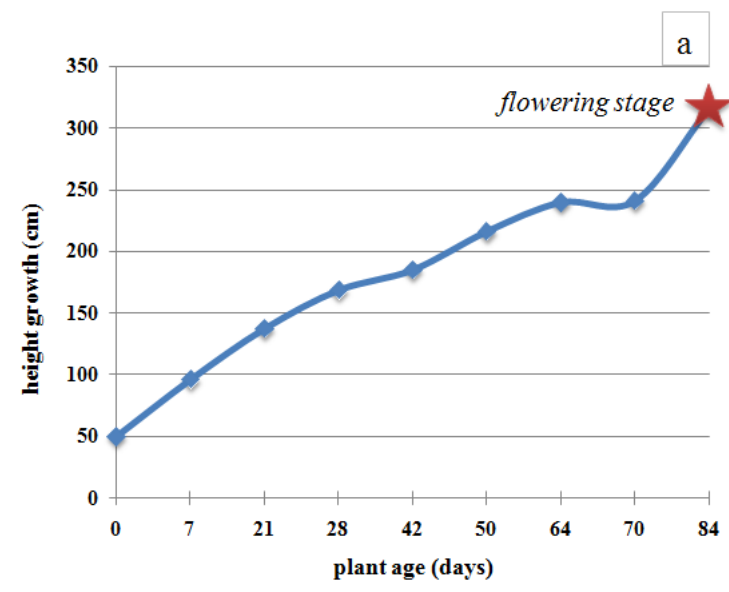

(a) Typha angustifolia Linn.

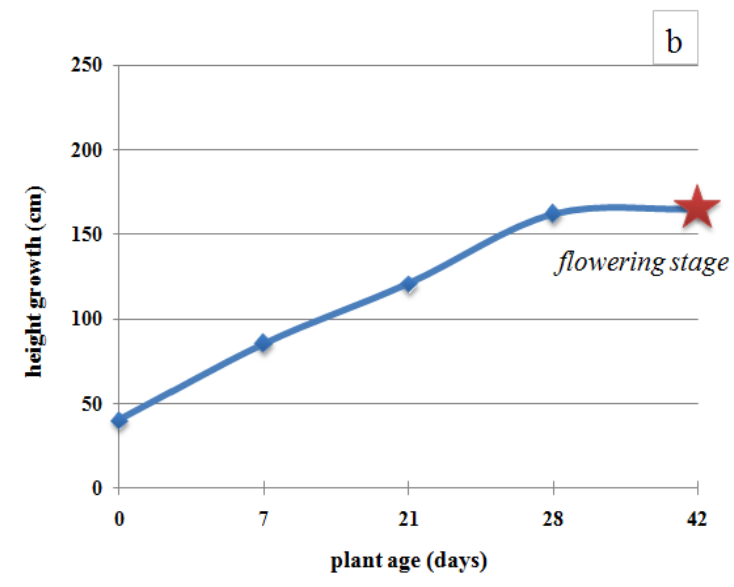

(b) Cyperus corymbosus Rottb.

Figure 3. Flowering stage of (a) Typha angustifolia Linn. and (b) Cyperus corymbosus Rottb. as used for community wastewater treatment at the Royal LERD project site in Phetchaburi province Thailand 


\subsection{Water Quality of Vertical Flow Constructed Wetlands}

The vertical flow constructed wetland (VFCW) has been used for 5 functions: firstly, soil media for filtration of larger materials; secondly, supporting unit for bacterial organic digestion processes to become inorganic matters, particularly plant nutrients and some chemicals; thirdly, accumulative chemicals of penetrated wastewater in vertical direction; fourthly, the air filling zone from the processes of thermo-osmosis, thermo-siphon and photosynthesis; and finally, phytoremadiation boundary by aquatic plant rhizomes. Such 5 -function property of the soil-sand filtration wetlands caused the effect of the water quality indicators of influent greater than the effluent as seen in Table 2 and Figure 4, although the removal efficiency of both aquatic plant species (Typha and Cyperus) were not different.

Table 2. Water quality indicators of vertical flow constructed wetland (VFCW) as collected at the consecutive distances from head of constructed wetlands for community wastewater treatment in Phetchaburi Province Thailand.

\begin{tabular}{|c|c|c|c|c|c|}
\hline \multirow{2}{*}{ Parameter } & \multirow{2}{*}{ Unit } & \multirow{2}{*}{ Influent } & \multicolumn{2}{|c|}{ Effluent } & \multirow{2}{*}{ p-value } \\
\hline & & & Typha angustifolia Linn. & Cyperus corymbosus Rottb. & \\
\hline $\mathrm{pH}$ & $(-)$ & 6.4 & 6.5 & 6.5 & 0.422 \\
\hline Total suspended solid (TSS) & $\mathrm{mg} / \mathrm{L}$ & 35.9 & 18.5 & 14.8 & 1.000 \\
\hline Total dissolved solid (TDS) & $\mathrm{mg} / \mathrm{L}$ & 460.0 & 466.2 & 449.6 & 1.000 \\
\hline Dissolved oxygen (DO) & $\mathrm{mg} / \mathrm{L}$ & 0.9 & 5.0 & 5.5 & 1.000 \\
\hline Biochemical oxygen demand (BOD) & $\mathrm{mg} / \mathrm{L}$ & 26.9 & 10.8 & 9.8 & 1.000 \\
\hline Total nitrogen $(\mathrm{TN})$ & $\mathrm{mg} / \mathrm{L}$ & 7.1 & 4.2 & 4.6 & 1.000 \\
\hline Total phosphorus (TP) & $\mathrm{mg} / \mathrm{L}$ & 4.2 & 2.6 & 2.1 & 1.000 \\
\hline Total coliform bacteria (TCB) & $\mathrm{MPN} / 100 \mathrm{ml}$ & $1.7 \times 10^{5}$ & $2.8 \times 10^{3}$ & $3.3 \times 10^{2}$ & 0.148 \\
\hline Fecal coliform bacteria (FCB) & $\mathrm{MPN} / 100 \mathrm{ml}$ & $6.8 \times 10^{4}$ & $9.4 \times 10^{2}$ & $1.3 \times 10^{2}$ & 1.000 \\
\hline
\end{tabular}

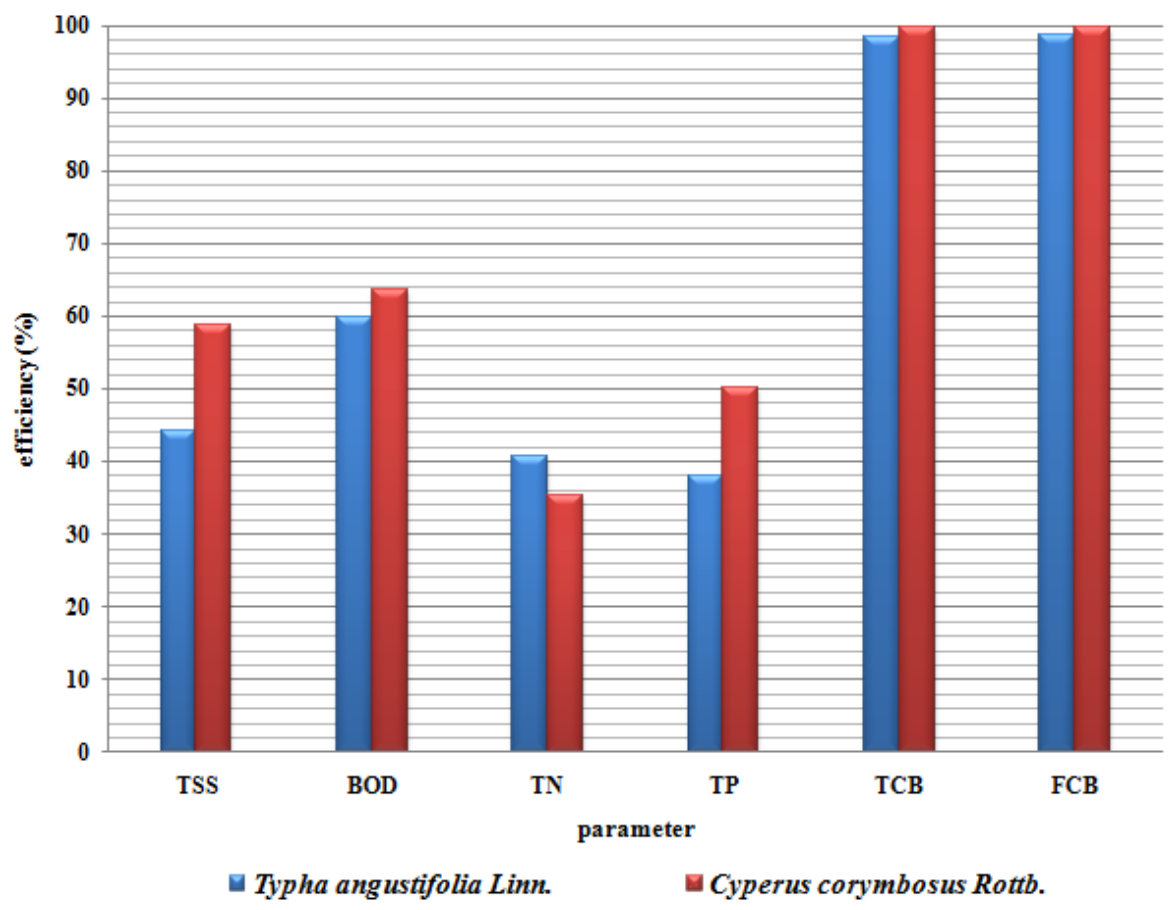

Figure 4. Efficiency of vertical flow constructed wetland (VFCW) as collected at the consecutive distances from head of constructed wetlands for community wastewater treatment in Phetchaburi province Thailand 


\subsection{Wastewater Treatment Efficiency}

Naturally, wetland is the most effective technology for wastewater treatment by not only filtration the larger size of objects and toxicants and also encouraging bacterial organic digestion for becoming to inorganic matter for plant growing.

\section{1) Small Vertical Flow Constructed Wetlands}

After analysis of filtrated wastewater samples ( 3 replications) on 25, 50, 75 and 100 meters from the beginning 0 to $100 \mathrm{~m}$. of those 7 main plots, the results found the averaged values as shown in Table 3. For making clear understanding the function of the vertical flow on grass-aquatic plant filtration plots under the concept of constructed wetland, the water quality indicators was taken an account with BOD and COD as the representative. The results indicated that the values of BOD was gradually decreased from the upper parts of plots to the lowest values at the ends as shown in Figure 5, while COD had the tendency to increase and to get the maximized peak at 50-m length from the inlet, then slowly decreasing until 100-m point of outlet. In principles, the organic matter has to be digested by aerobic and anaerobic processes at the top-layer wastewater and the middle-layer soil growing media during vertical flowing to the bottom of constructed wetlands. The received products from bacterial digestion processes (causing the decrease of BOD) are expected to be inorganic materials as well as some elements and heavy metals which can be removed together with the treated wastewater and causing to increase more concentration of COD at 50-m length, but it trends to decrease because of less product from those organic digestion. In other words, the values of COD are depended on the values of BOD which are related to the rate of bacterial organic digestion.

Table 3. Influences of infiltration process due to vertical flow of Phetchaburi municipal wastewater along with the $100-\mathrm{m}$ plots of constructed wetlands

\begin{tabular}{|c|c|c|c|c|c|c|c|c|c|c|c|c|c|}
\hline \multirow{2}{*}{ No. } & \multirow{2}{*}{$\begin{array}{c}\text { Plant } \\
\text { Species }\end{array}$} & \multirow{2}{*}{$\begin{array}{l}\text { Distance } \\
(\mathrm{m} .)\end{array}$} & \multicolumn{10}{|c|}{ Averaged Values of Compound/Element (mg/l) } & \multirow{2}{*}{ Remarks } \\
\hline & & & COD & BOD & $\mathrm{N}$ & $\mathrm{P}$ & $\mathrm{SS}$ & $\mathrm{pH}$ & $\mathrm{Cd}$ & $\mathrm{Pb}$ & $\mathrm{Ni}$ & As & \\
\hline \multirow[t]{5}{*}{1} & Control Plot & 0 & 95.20 & 43.70 & 7.10 & 4.20 & 35.90 & 6.4 & 0.02 & 0.13 & 0.13 & 17.40 & Influent \\
\hline & & 25 & 164.00 & 5.70 & - & - & - & - & 0.18 & 0.76 & 0.95 & 5.40 & \\
\hline & & 50 & 277.00 & 7.20 & - & - & - & - & 0.07 & 0.42 & 0.17 & 5.90 & \\
\hline & & 75 & 253.00 & 6.90 & - & - & - & - & 0.08 & 0.33 & 0.26 & 2.00 & \\
\hline & & 100 & 190.00 & 5.70 & 4.80 & 2.60 & 40.40 & 7.6 & 0.08 & 0.34 & 0.18 & 8.70 & Effluent \\
\hline \multirow[t]{5}{*}{2} & Typha & 0 & 95.20 & 43.70 & 7.10 & 4.20 & 35.90 & 6.4 & 0.02 & 0.13 & 0.13 & 17.40 & \\
\hline & & 25 & 154.00 & 4.40 & - & - & - & - & 0.07 & 0.36 & 0.26 & 2.40 & Influent \\
\hline & & 50 & 209.00 & 2.60 & - & - & - & - & 0.10 & 0.55 & 0.84 & 7.00 & \\
\hline & & 75 & 180.00 & 1.70 & - & - & - & - & 0.06 & 0.43 & 0.19 & 4.40 & \\
\hline & & 100 & 141.00 & 2.10 & 4.20 & 2.60 & 18.50 & 6.5 & 0.06 & 0.39 & 0.16 & 24.80 & Effluent \\
\hline \multirow[t]{5}{*}{3} & Cyperus & 0 & 95.20 & 43.70 & 7.10 & 4.20 & 35.90 & 6.4 & 0.02 & 0.13 & 0.13 & 17.40 & Influent \\
\hline & & 25 & 154.00 & 7.80 & - & - & - & - & 0.05 & 0.27 & 0.24 & 13.80 & \\
\hline & & 50 & 209.00 & 4.20 & - & - & - & - & 0.15 & 0.70 & 0.83 & 2.30 & \\
\hline & & 75 & 180.00 & 2.00 & - & - & - & - & 0.14 & 0.50 & 0.89 & 9.60 & \\
\hline & & 100 & 141.00 & 2.50 & 4.60 & 2.20 & 14.80 & 6.6 & 0.14 & 0.57 & 0.86 & 11.60 & Effluent \\
\hline
\end{tabular}
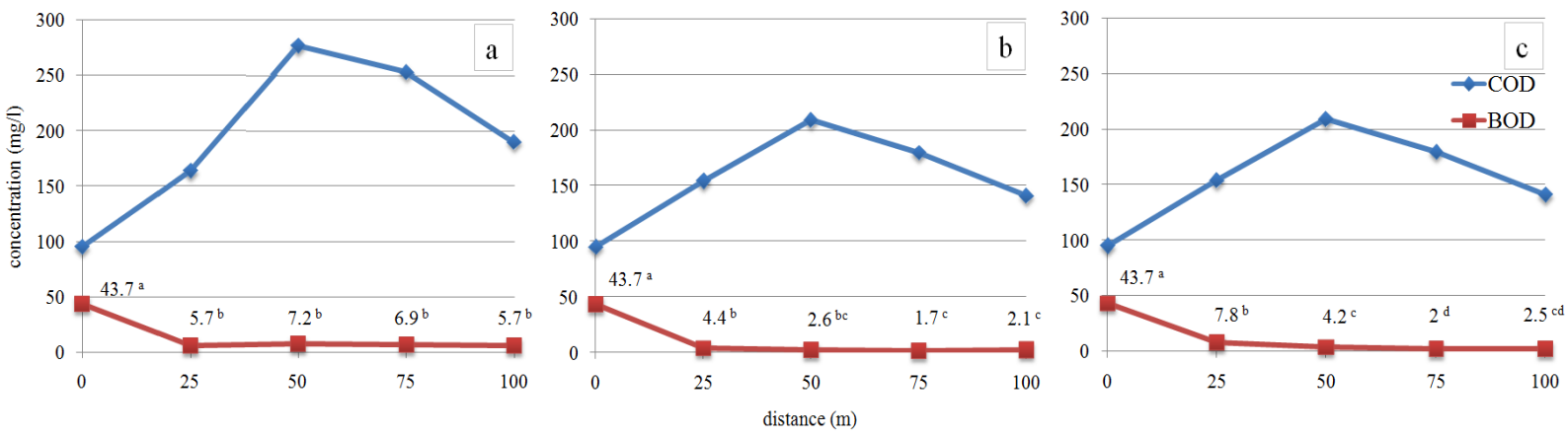

Figure 5. Characters of BOD and COD as released by vertical flow through soil growing media of grass-aquatic plant filtration plots under the concept of constructed wetland; (a) control plot, (b) Typha angustifolia Linn. and

(c) Cyperus corymbosus Rottb 
Theoretical speaking, there are hidden two natural processes; firstly, aquatic plant photosynthesis during daytime to provide oxygen as the processing (Sooknah and Wilkie, 2004; Hadad et al., 2006; Tanji et al., 2006), and secondly, thermo-osmosis process produces oxygen to bacteria for organic digestion during photosynthesis process of very young leaves, containing aerenchyma cells, of aquatic plants (Deubigh and Raumann, 1952; Bearnan, 1957; Srivastav and Avasthi, 1975; Grosse, 1989; Buchel and Grosse, 1990; Grofse and Bauch, 1991) The size of the constructed wetland has been used for wastewater treatment from various point sources for long period of time in which it depends on the amount of polluted wastewater, space availability, and topographical characteristics but normally varying on depth 0.3 to $1.0 \mathrm{~m}$, surface area 100 to $600 \mathrm{~m}^{2}$; mostly rectangular-shaped surface area and 1:1.000 slope (Tripathi and Shukla, 1991; Jenssen et al., 1993; Juwarkar et al., 1995; Ahn and Mitsch, 2002; Stottmeister et al., 2003; Maine et al., 2006; Yang et al., 2008; Li et al., 2009; Stefanakis and Tsihrintzis, 2012). The Photosynthetic rate of wetland plants were highly correlated with light intensity and temperature due to influence of oxygen evolving activities and disposal efficiency. The photosynthetic characteristics of wetland species can affect their ability to provide oxygen and remove pollutants (Huang et al., 2010). Furthermore, oxygen transfer and oxygen consumption in constructed wetland revealed with flowing techniques since areal-based oxygen consumption rates in vertical flow system was higher than horizontal flow system (Nivala et al., 2013; Bialowiec et al., 2014). The findings demonstrated that oxygen from thermo-osmosis process was important role for organic digestion in systems.

2) Five-Consecutive Oxidation Ponds

The Oxidation pond treatment system at Laem Phak Bia is wastewater treatment system of the municipality of Phetchaburi province that is a facultative type. It is designed to accept wastewater of about $10,000 \mathrm{~m}^{3} / \mathrm{day}$. The system comprises a series of five large, shallow earthen basins: one sedimentation pond, three oxidation ponds, and one stabilization pond. The characteristics of this system are summarized in Table 4 . The system Phetchaburi occupies an area of $154,178.5 \mathrm{~m}^{2}$. Each pond is separated by an earthen 3-m-width berm a ratio of vertical to horizontal distance of 1:2. Grass is planted at the edge of the pond to protect soil erosion. The outlet structure is a spillway that is constructed as far away as possible from the inlet structure.

Table 4. Characteristics of the model of lagoon treatment system at Laem Phak Bia

\begin{tabular}{|c|c|c|c|c|c|}
\hline Order & Pond & Depth) $\mathrm{m}($ & Pond type & Process/Treatment & $\begin{array}{l}\text { Retention time } \\
\quad \text { (days) }\end{array}$ \\
\hline 1 & Sedimentation & 2.5 & $\begin{array}{l}\text { Anaerobic or } \\
\text { Facultative }\end{array}$ & $\begin{array}{l}\text { Sedimentation and primary treatment } \\
\text { through facultative digestion }\end{array}$ & 7 \\
\hline 2 & Oxidation & 2.0 & Facultative & $\begin{array}{l}\text { Addition of } \mathrm{O}_{2} \text { thorough themo-siphon, } \\
\text { facultative digestion and bacteria removal }\end{array}$ & 7 \\
\hline 3 & Stabilization & 1.7 & Aerobic & Wastewater polishing and algae removal & 7 \\
\hline \multicolumn{5}{|c|}{ Total } & 21 \\
\hline
\end{tabular}

Wastewater from municipality is pumped via HDPE pipe for a distance of $18.5 \mathrm{~km}$ to the project area into the sedimentation pond. No additional pumping is necessary, from one pond and enters to the next from the bottom. The BOD concentration was decreased by anaerobic organic digestion process in 18.5-km. HDPE pipe (Poommai et al., 2013). Effluent was discharged after being retained in the system for 21-28 days as the natural purification processes occur. The rectangular weir was introduced to increase the efficiency by oxygen transfer into wastewater as flowing over the weir crest which presented $0.03-\mathrm{m}$ depth showed the highest efficiency of oxygen diffusion and it decreased when water depth increased (Poommai et al., 2012). The quality of treated water meets the effluent wastewater quality standard. The Efficiency of the system is about 50-70\% (Table 5). 
Table 5. Water quality of lagoon treatment system for Phetchaburi municipal wastewater treatment

\begin{tabular}{|c|c|c|c|c|c|c|c|c|c|}
\hline \multirow[t]{2}{*}{ Ponds } & \multirow{2}{*}{$\begin{array}{l}\text { Sample } \\
\text { Stations }\end{array}$} & \multicolumn{8}{|c|}{ Water Quality Indicator (mg/L) } \\
\hline & & BOD & SS & Nitrate & Nitrite & Ammonia & $\mathrm{TKN}$ & Phosphate & Potassium \\
\hline Klongyang & input & 31.20 & 12.80 & $<0.01$ & 0.013 & $<0.05$ & 1.930 & 1.10 & 14.10 \\
\hline Collection Pond & output & 45.07 & 17.73 & 0.067 & 0.013 & $<0.05$ & $<0.05$ & 3.03 & 15.77 \\
\hline Sedimentation & input & 42.20 & 16.40 & 0.037 & 0.003 & $<0.05$ & 0.657 & 2.27 & 10.57 \\
\hline Pond & output & 21.50 & 21.87 & 0.153 & $<0.002$ & 2.437 & 5.647 & 2.77 & 15.87 \\
\hline $\begin{array}{l}\text { Oxidation Pond } \\
\text { No.1 }\end{array}$ & output & 7.33 & 59.00 & 0.380 & 0.297 & $<0.05$ & $<0.05$ & 1.37 & 23.10 \\
\hline $\begin{array}{l}\text { Oxidation Pond } \\
\text { No.2 }\end{array}$ & output & 10.87 & 65.10 & 0.397 & $<0.002$ & $<0.05$ & $<0.05$ & 1.37 & 18.87 \\
\hline $\begin{array}{l}\text { Oxidation Pond } \\
\text { No.3 }\end{array}$ & output & 8.50 & 38.17 & 0.137 & 0.018 & $<0.05$ & $<0.05$ & 1.07 & 22.87 \\
\hline Polishing Pond & output & 16.40 & 54.90 & 0.177 & 0.006 & $<0.05$ & $<0.05$ & 0.43 & 26.60 \\
\hline
\end{tabular}

The treatment processes in lagoon treatment were photosynthesis and thermo-siphon. The thermo-siphon process produces oxygen during evaporation process that causes water surface cooling due to heat being absorbed about $583 \mathrm{~g}$-calories for evaporating $1 \mathrm{~g}$ of water, consequently cool surface water moving vertically down to the bottom of wastewater treatment ponds together with free oxygen to bacteria for organic digestion process (Mirmov and Belyakova, 1982; Mevi-Schutz and Grosse, 1988; Ameth and Stichlmair, 2001; Gehlin et al., 2003; Watanabe et al., 2012). Sedimentation pond was the primary treatment of influent where settleable solids were removed. The digestion of organic matters carried out by microorganism under aerobic, facultative and anaerobic conditions in oxidation ponds. Upper portion were an anaerobic zone maintained by oxygen generated by algae and penetration of oxygen from the atmosphere through thermo-siphon process. Symbiotic related exist in this zone. Bacteria use oxygen as an electron acceptor to oxidize the organic wastes to stable product i.e. carbon dioxide, nitrate and phosphate. Algae used these compounds and with sunlight to produce oxygen in photosynthesis. Middle portion were a facultative zone where the volume of oxygen fluctuates based on level of wind action and penetration of sunlight. Therefore, microorganisms in this zone must be capable of adjusting their microbial activity to the change of oxygen level. Bottom portion were an anaerobic zone because stagnant conditions prohibit oxygen transfer to this region. Organic acids and gases were the product from decomposition in this zone and became to carbon source and energy source for microorganism in the aerobic zone. The finally pond was a polishing pond where algae was removed through natural die off process due to lack of nutrients. Furthermore, effluent after treated wastewater flowed over weir crest that finding BOD under standard and also the decreasing of total coliform bacteria and fecal coliform bacteria, particularly the pathogenic bacteria decreasing down to almost zero MPN/100 ml. Because of the effect of solar radiation to dissolved oxygen (DO) and hydrogen peroxide $\left(\mathrm{H}_{2} \mathrm{O}_{2}\right)$ which were employed for bacterial organic digestion process in wastewater treatment ponds. The solar radiation showed solar energy between $0-750 \mathrm{~W} / \mathrm{m}^{2}$ all together with UV-A, UV-B, spectrum and net radiation (Pattamapotoon et al., 2013).

\subsection{VFCW Filtration of Toxic Chemicals}

It is remarkable that whenever the remediation technique has to be applied for extract some toxic chemicals which might be used for gaining specific profits, particularly for growing cash crops. In order to prove such principles, the roots (rhizomes) and stems of Typha and Cyperus were sampled for analyzing $\mathrm{N}, \mathrm{P}, \mathrm{K}, \mathrm{Cu}, \mathrm{Zn}, \mathrm{Pb}$, $\mathrm{Cd}$ and $\mathrm{Hg}$, the analyzed results were shown in Table 6. The research results were indicated the amount of N, P, and $\mathrm{K}$ higher in stems than in rhizomes accordance with identification of Typha and Cyperus as hyper-accumulative aquatic plants of macronutrients like $\mathrm{N}, \mathrm{P}$, and $\mathrm{K}$ in its green stems rather than rhizomes. In contrary, the elements $\mathrm{Cu}$ and $\mathrm{Zn}$ which are the micronutrients for plant growth found higher values in rhizomes more than stems because of very slow translocation of $\mathrm{Cu}$ and $\mathrm{Zn}$ from rhizomes to stems, and mostly accumulating around rhizomes (Delgalo et al., 1993). Furthermore, the heavy metals ( $\mathrm{Pb}, \mathrm{Cd}$ and $\mathrm{Hg}$ ) found in stems more than rhizomes of Typha and Cyperus since both species has been identified as fast growing aquatic plants that uptaking every elements for short period of time. This is why some heavy metals can be distributed to the green leaves of Typha and Cyperus as taken for experimenting under the phytoremediation technique and constructed wetland concept. 
Table 6. Elements up taking by Typha and Cyperus on vertical-flow constructed wetlands during 1997-1999 at the Royal LERD project site

\begin{tabular}{ccccccc}
\hline \multirow{2}{*}{ No. } & \multirow{2}{*}{ Elements } & Unit & \multicolumn{2}{c}{ Typha } & \multicolumn{2}{c}{ Cyperus } \\
\cline { 3 - 6 } & & Root & Stem & Root & Stem \\
\hline 1. & $\mathrm{~N}$ & percentage by oven & 0.87 & 0.87 & 0.69 & 1.11 \\
2. & $\mathrm{P}$ & percentage by oven & 0.29 & 0.26 & 0.22 & 0.18 \\
3. & $\mathrm{~K}$ & percentage by oven & 0.90 & 3.42 & 1.18 & 3.97 \\
4. & $\mathrm{Cu}$ & $\mathrm{mg} / 1$ & 6.60 & 3.30 & 9.00 & 4.00 \\
5. & $\mathrm{Zn}$ & $\mathrm{mg} / 1$ & 24.60 & 16.00 & 66.30 & 16.00 \\
6. & $\mathrm{~Pb}$ & $\mathrm{mg} / 1$ & 10.30 & 0.00 & 7.00 & 36.30 \\
7. & $\mathrm{Cd}$ & $\mathrm{mg} / 1$ & 3.50 & 3.00 & 2.40 & 6.40 \\
8. & $\mathrm{Hg}$ & $\mu \mathrm{g} / 1$ & & & 1.85 \\
\hline
\end{tabular}

Actually, wetland is occurred between the terrestrial and aquatic systems in order to absorb the toxic contaminants by humus, organic matters, and soils before draining away to stream or river. Aquatic plant has eventually to remove contaminants from wastewater and soils as growing units through root system under the osmotic pressure during the photosynthesis processing, then the elements are translocated to accumulate in all parts of vegetative organ, but it depends on the degree of toxic chemical contaminants and aquatic plant species (Tateuyama et al., 1967; Reddy et al., 1990; Rai et al., 1994; De Souza et al., 1999; Marin and Ayele, 2003; Pulford and Watson, 2003; Xia and Ma, 2006; Gupta and Sinha, 2007; Wahla et al., 2008; Thaipichitburapa et al., 2010; Zaier et al., 2010; Chunkao et al., 2012).

\subsection{Royal LERD Project Benefits}

It is noted that the outcomes of BOD treatment efficiency equivalent to $88 \%$ for oxidation ponds and $91 \%$ for constructed wetlands. The main points to produce an effect were not only nature-by-nature process but also the techniques of 5-day stagnating on vertical flow and 2-day releasing the treated wastewater from soil-sand-gravel layering constructed wetlands. The BOD concentration of estuarine water in mangrove forest, over muddy beach and on-site seashore indicated as 5.7, 2.2 and $2.5 \mathrm{mg} / \mathrm{L}$. Surprisingly, they were so much low when compared with wastewater from fresh food market $(546.6 \mathrm{mg} / \mathrm{L})$ and in the municipal culverts $(164.1 \mathrm{mg} / \mathrm{L}) \mathrm{on}$ which the constructed wetland was shown high treatment efficiency.

The treated wastewater which obtained from oxidation ponds and constructed wetlands was still treated by the natural mangrove forest and called as "secondary treatment" of such treated wastewater before flowing into muddy beach and seashore in part of the Gulf of Thailand. It could be the vertical flow constructed wetlands and oxidation pond wastewater treatment that worked together with the King's initiative nature-by-nature process causing high rate of bacterial organic digestion processes. Consequently, the abundances of fishes, crams, crabs, muscles, shells and other marine animals have been existed on the Royal LERD project site nearby areas. Benefits from the Royal LERD Project can be described as follows:

1) Benefits from solid waste disposal or the concrete box system include compost that can be Utilized to grow flowers. Compost can ideally be mixed with a binding agent and compressed into cubes and used to restore deteriorated mangrove areas. Biological gas, namely methane, from the system was reported to be as high as $60 \%$ of the total gas generated under the condition of absence of oxygen. This gas can be utilized for various activities in households such as cooking, lighting and fueling engine.

2) Benefits from wastewater treatment systems are utilization of oxidation ponds for aquaculture. Fish farming can be carries out without providing any feedings. The measurement of Nile tilapia (Oreochromis niloticus) growth was taken from the third pond in which the water quality was in effluent standard. The fish growth model found that the predicted fish weight revealed with biochemical oxygen demand (BOD), Dissolved oxygen demand (DO), water temperature, concentration of plankton, and ammonia (Dampin et al., 2012) Fish are also safe for consumption. Treated wastewater can be used to grow plants and grass that withstand flooding. The productivity of the grass was also found to be high enough to feed cattle.

3) Benefits from sludge include usage of sludge with soil as a substrate to grow flowers and plants. Supakata et al. (2011) showed that using moist sewage sludge as a new source for growing rice was an alternative community wastewater treatment with agricultural benefit and ease management (saved time and space). The finding presented moist sewage sludge piled at the depth of $30 \mathrm{~cm}$ could be used to grow rice (Oryza sativa) with sufficient nitrogen. Furthermore, Semvimol et al. (2014) presented that gas volume from sludge of oxidation 
ponds for community wastewater treatment in which organic matters of both units were digested through the nature-by-nature process in anaerobic condition produced gas $1.8 \mathrm{ml} / \mathrm{g}$ (oven dry weight), methane concentration in range $545,686-9,560,606 \mathrm{mg} / \mathrm{L}$.

Socially, the social behavior that causes solid waste and wastewater problems included activities related to food preparation and consumption. People are aware and accept the project. Dissemination of environmental knowledge and public relations must gear toward specific social target group that included commercial, industry, tourism, recreation and the mix. The latter group was mostly the agricultural community.

\subsection{Dissemination of Research Results}

The Royal LERD project is aimed to disseminate all research results of community wastewater treatment and garbage disposal to the people of Thailand in order to manage their home environment and also to human settlement, villages, urban areas, fresh-food markets, shopping centers, factories as the same as schools, colleges, medical centers, scientific laboratories, tourism facilities, government offices and public areas. The dissemination program has been planned on 5 manners as follows:

\section{1) On-Site Studies}

There have been recorded the academic visitors a half of million people that came to on-site visit at the Royal LERD project site on Laem Phak Bia sub-district, Ban Laem district, Phetchaburi province, Thailand as shown in Table2. The typicality of on-site visitors was composed of school boys and girls, school teachers, university professors, technocrats, researchers, environmentalists, local administrators, high ranking administrators, policy makers, general population, foreigners of all continents from Asia, North America, South America, Europe, Africa and Australia.

\section{2) Short-Course Training}

Actually, the community wastewater treatment and garbage disposal under the King's initiative nature-by-nature processes can be said as easy in practicing but they are very difficult to understand due to the scientific mechanisms. Therefore, short-course training program would be necessary to organize for some government and private sectors, local administration offices, schools and universities to know how to manage community wastewater treatment and garbage disposal. There were a lot of the said units that request to train the personnel for on-site and out-site programs as shown in Table2, approximately more than 7 programs per year.

\section{3) Academic Servicing}

Academic servicing would be the most important program for disseminating the in-depth knowledge on how community wastewater to be treated and garbage to be disposed in terms of scientific processing driving forces from nature-by-nature process. Such intention could be brought to ease the community wastewater treatment and garbage disposal and also to transfer knowledge to another people without doubts. However, there were academic servicing more than 5 programs per month onto industrial factories, schools, universities and production companies as shown in Table2. It would be noted that the Royal LERD project on community wastewater treatment and garbage disposal under the nature-by-nature processes have been known since 1990 among the practical men in the whole country.

\section{4) Publishing Materials and VDO Dissemination}

The Royal LERD project has prepared the publication of brochures, leaflets and articles that concern with knowledge on how to treat the community wastewater and to dispose the community garbage under the nature-by-nature processes. Moreover, the project team sent the papers to participate both the national and international conferences on oral presentation and poster sessions as the same as submitting the research papers to publish in both the national and international journals. In order to make clear on know-how to eliminate the community wastewater and garbage, the VDO cassettes have been made in both Thai and English versions for the visitors to learn before looking around the demonstration areas and also distributing as a gift to specified groups.

\section{5) Radio Broadcasting and TV Telecasting}

Generally speaking, the Royal LERD project for community wastewater treatment and garbage disposal under the nature-by-nature processes is one part of all 4,350 Royal projects that spread out around the country. They are in groups of agriculture (cropping, livestock, aquaculture), poverty elimination, water and irrigation, reforestation and headwater rehabilitation, public health and environmental protection. Undoubtedly, there must be at least one article to be telecasted on TV and broadcasted on radio every day. 


\section{Conclusion}

The community wastewater treatment with small vertical flow constructed wetlands under the King's initiative on nature-by-nature processes has been conducted since 1990 by transferring wastewater from Phetchaburi municipal (BOD more than $1000 \mathrm{mg} / \mathrm{L}$ ) through drainpipes (BOD about $450 \mathrm{mg} / \mathrm{L}$ ) to Klongyang collection pond (BOD $230 \mathrm{mg} / \mathrm{L}$ ) and then flowing along $18.5-\mathrm{km}$ HPDE pipe by pumping before becoming the Influent (BOD about $70 \mathrm{mg} / \mathrm{L}$ ) of growing Typha and Cyperus in the small VFCW units. Due to vertical flow through soil, sand and gravel media at $0,25,50,75$ and $100 \mathrm{~m}$. length of constructed wetlands, the results found BOD gradually decreasing but COD increasing to meet the peak at the length of $50 \mathrm{~m}$ for all study units as used for serving in phytoremediation technique. In so far, the cutting periods were found 45 days for Cyperus and 90 days for Typha. The study was also paid more attention on the accumulation of macronutrients $(\mathrm{N}, \mathrm{P}, \mathrm{K})$ and heavy metals $(\mathrm{Pb}, \mathrm{Cd}, \mathrm{Hg})$ in stems more than rhizomes but opposite direction on micronutrients $(\mathrm{Cu}$ and $\mathrm{Zn})$. In conclusion, the oxidation pond and vertical flow constructed wetland together with the phytoremediation technique would be characterized as the most valuable community wastewater treatment system.

\section{Acknowledgments}

We are indebted to His Majesty the King Bhumibol Adulyadej, the King of Thailand for his contribution in creating invaluable knowledge not only to Thai people but also to the people of the world. We are also in debt to Princess Sirindhorn, the chairperson of the Chaipattana Foundation, to conduct this project and supporting the Royal project extension to the people of Thailand and the world to have incalculable knowledge. We would like to give thanks to the staff of Eco-Science Community Research Group(ESCRG), Department Environmental Science, Faculty of Environment, Kasetsart University for facilitating the research personnel and laboratories. With appreciation, we are thankful to our colleagues of "The King's Royally Initiative Laem Phak Bia Research and Development Project at Laem Phak Bia Sub-District, Ban Laem District, Phetchaburi Province, Thailand" for their hard working since 1990 .

\section{References}

Ahn, C., \& Mitsch, W. J. (2002). Evaluating the use of recycled coal combustion products in constructed wetland: An ecological-economic modeling approach. Ecological Modelling, 150, 117-140. http://dx.doi.org/10.1016/S0304-3800(01)00477-X

Arneth, S., \& Stichlmair, J. (2001). Characteristics of thermosiphon reboilers. International Journal of thermal Sciences, 40(4), 385-391. http://dx.doi.org /10.1016/S1290-0729(01)01231-5

Bearnan, R. J. (1957). The thermo-osmosis of rare gases through a rubber membrane. Journal of Physical Chemistry, 61(6), 708-714. http://dx.doi.org /10.1021/j150552a002

Bialoweic, A., Albuquerque, A., \& Randerson, P. F. (2014). The influence of evapotranspiration on vertical flow subsurface constructed wetland performance. Ecological Engineering, 67, 89-94. http://dx.doi.org/ 10.1016/ j.ecoleng.2014.03.032

Boyd, C. E., \& Vickers, D. H. (1971). Variation in the elemental content of Eichhonia crassipes. Hydrobiologia, 38, 409-414. http://dx.doi.org /10.1007/BF00036546

Buchel, H. B., \& Grosse, W. (1990). Localization of the porous partition responsible for pressurized gas transport in Alnus glutinosa (L.) Gaertn. Tree Physiology, 6, 247-256. http://dx.doi.org /10.1093/treephys/6.3.247

Chunkao, K., Nimpee, C., \& Duangmal, K. (2012). The King's initiative using water hyacinth to remove heavy metals and plant nutrients from wastewater through Bueng Makkasan in Bangkok, Thailand. Ecological Engineering, 39, 40-52. http://dx.doi.org /10.1016/j.ecoleng.2011.09.006

Dampin, N, Tarnchalanukit, W., Chunkao, K., \& Maleewong, M. (2012). Fish growth model for Nile tilapia (Oreochromis niloticus) in wastewater oxidation pond, Thailand. Procedia Environmental Sciences, 13, 513-524. http://dx.doi.org/10.1016.j.proenv.2012.01.042

Delgado, M., Bigeriego, M., \& Guarniola, E. (1993). Uptake of $\mathrm{Zn}, \mathrm{Cr}$, and Cd by water hyacinths. Water Research, 27(2), 269-272. http://dx.doi.org/ 10.1016/0043-1354(93)90085-V

Denbigh, K. G., \& Raumann, G. (1952). The thermo-osmosis of gas through a membrane. II. Experimental Proceeding of the Royal Society A: Mathematical, Physical and Engineering Sciences, 210(1103), 518-533. http://dx.doi.org /10.1098/rspa.1952.0017

Gehlin, S., Hellstrom, G., \& Nordell, B. (2003). The influence of the thermosiphon effect on the thermal response test. Renewable Energy, 28(14), 2239-2254. http://dx.doi.org/10.1016/S0960-1481(03)00129-0 
Grosse, W. (1989). Thermo-osmosis air transport in aquatic plants affecting growth activities and oxygen diffusion to wet soils. In D. A. Hammer (Ed.), Constructed Wetland for Wastewater Treatment (pp.469-476). USA: Lewis Publisher, Inc.

Grosse, W., \& Bauch, C. (1991). Gas transfer in floating-leaved plants. Plant Ecology, 97(2), 185-192. http://dx.doi.org/10.1007/BF00035391

Gupta, A. K., \& Sinha, S. (2007). Phytoextraction capacity of the plants growing on tannery sludge dumping sites. Bioresource Technology, 98(9), 1788-1794. http://dx.doi.org/10.1016/j.biortech.2006.06.028

Hadad, H. R., Maine, M. A., \& Bonetto, C. A. (2006). Macrophyte growth in a plot-scale constructed wetland for industrial wastewater treatment. Chemosphere, 63(10), 1744-1753. http://dx.doi.org/10.1016/ j.chemosphere.2005.09.014

Huang, J., Wang, S. H., Yan, L., \& Zhang, Q. S. (2010). Plant photosynthesis and its influence on removal efficiencies in contructed wetlands. Ecological Engineering, 3, 1037-1043. http://dx.doi.org/10.1016/ j.ecoleng.2010.04.016

Ivanov, Y., Watanabe, H., Hamabe, M., Kawahara, T., Sun, J., \& Yamaguchi, S. (2012). Observation of the thermosiphon effect in the circulation of liquid nitrogen in HTS cable cooling system. Physics Procedia, 27, 368-371. http://dx.doi.org/10.1016/j.phpro.2012.03.487

Jenssen, P. D., Mahlum, T., \& Krogstag, T. (1994). Potential use of constructed wetlands for wastewater treatment in northern environment. Water Science and Technology, 28(10), 149-157.

Juwarkar, A. S., Oke, B., Juwarkar, A., \& Patnaik, S. M. (1995). Domestic wastewater treatment through constructed wetland in India. Water Science and Technology, 32(3), 291-294. http://dx.doi.org/ 10.1016/0273-1223(95)00637-0

Li, S., Zhang, K., Zhou, S., Zhang, L., \& Chen, Q. (2009). Use of dewatered municipal sludge on Canna growth in pot experiments with a barren clay soil. Waste Management, 29(6), 1870-1876. http://dx.doi.org/ 10.1016/j.wasman.2008.12.007

Maine, M. A., Sune, N., Hadad, H., Sanchez, G., \& Bonetto, C. (2006). Nutrient and metal removal in a constructed wetland for wastewater treatment from a metallurgic industry. Ecological Engineering, 26(4), 341-347. http://dx.doi.org/ 10.1016/j.ecoleng.2005.12.004

Marin, J., \& Ayele, J. (2003). Removal of some heavy metal cations from aqueous solutions by spruce sawdust. II. Adsorption-desorption through column experiments. Environmental Technology, 24(4), 491-502. PubMed ID: 12755450.

Mevi-Schutz, J., \& Grosse, W. (1988). The importance of water vapour for the circulating air flow through Nelumbo nucifera. Journal of Experimental Botany, 39(9), 1231-1236. http://dx.doi.org/10.1093/jxb/39.9.1231

Mirmov, N. I., \& Belyakova, I. G. (1982). Heat liberation during vapor condensation in a thermosiphon. Journal of Engineering Physics, 43(3), 970-974. http://dx.doi.org /10.1007/BF00827237

Nivala, J., Wallac, S., Headley, T., Kassa, K., Brix, H., Afferden, M. V., \& Müller, R. (2013). Oxygen transfer and consumption in subsurface flow treatment wetlands. Ecological Engineering, 61, 544-554. http://dx.doi.org/10.1016/j.ecoleng. 2012.08.028

Pattamapitoon, T., Siriroj, P., Pakkomg, P., \& Chunkao, K. (2013). Nature of solar radiation as encouraged to produce an increment of dissolved oxygen and hydrogen peroxide in oxidation ponds for community wastewater treatment at H.M. the King's LERD Project site in Phetchabuti Province, Thailand. Modern Applied Science, 7(6), 26-41. http://dx.doi.org/10.5539/mas.v7n6p26

Pedescoll, A., Sidrach-Cardona, R., Sánchez, J. C., \& Bécares, E. (2013). Evapotranspiration affecting redox conditions in horizontal constructed wetlands under Mediterranean climate: Influence of plant species. Ecological Engineering, 58, 335-343. http://dx.doi.org/10.1016/j.ecoleng.2013.07.007

Phewnil, O., Chunkao, K., Pattamapitoon, T., Intaraksa, A., Chueawong, O., Chantrasoon, C., \& Boonprakong, T. (2014). Choosing aquatic plant species for high wastewater treatment efficiency through small wetland. Modern Applied Science, 8(4), 187-194. http://dx.doi.org/10.5539/mas.v8n4p187

Poommai, S., Chunkao, C., \& Bualert, B. (2012). Variation of oxygen transfer along the rectangular weir crest distance of wastewater treatment pond. Procedia Environmental Sciences, 13, 498-512. http://dx.doi.org/10.1016/j.proenv.2012.01.041 
Poommai, S., Chunkao, C., Narauchid, D., Boonmang, S., \& Nimpee, C. (2013). Determining the in-pipe anaerobic processing distance before draining to oxidation pond of municipal wastewater treatment. International Journal of Environmental Science and Development, 4(2), 157-162. http://dx.doi.org/10.7763/IJESD.2013.V4.326

Pulford, I. D., \& Watson, C. (2003). Phytoremediation of heavy metal-contaminated land by trees-a review. Environment International, 29(4), 529-540. http://dx.doi.org/10.1016/S0160-4120(02)00152-6

Rai, S., Hasan, S. H., Rupainwar, D. C., \& Sharma, Y. C. (1994). Removal of cadmium from wastewater by water hyacinth. International Journal of Environmental Studies, 46, 251-256. http://dx.doi.org/10.1080/ 00207239408710930

Reddy, K. R., Agami, M., \& Tucker, J. C. (1990). Influence of phosphorus growth and nutrient storage by water hyacinth (Eichhornia crassipes (Mart.) Solms) plants. Aquatic Botany, 37(4), 355-365. http://dx.doi.org/10.1016/0304-3770(90)90021-C

Semvimol, N., Chunkao, K., \& Bualert, S. (2014). Gas extraction from sludge as acquired from oxidation ponds of community wastewater and cassava-factory wastewater treatment through nature-by-nature processes. Modern Applied Science, 8(2), 171-183. http://dx.doi.org/10.5339/mas.v8n2p171

Sooknah, R. D., \& Wilkie, A. C. (2004). Nutrient removal by floating aquatic macrophytes cultured in anaerobically digested flushed dairy manure wastewater. Ecological Engineering, 22(1), 27-42. http://dx.doi.org/ 10.1016/j.ecoleng.2004.01.004

Srivastava, R. C., \& Avasthi, P. K. (1975). Non-equilibrium thermodynamics of thermo-osmosis of water through kaolinite. Journal of Hydrology, 24(1-2), 111-120. http://dx.doi.org/10.1016/0022-1694(75)90145-6

Stefanakis, A. I., \& Tsihrintzis, V. A. (2012). Effects of loading, resting period, temperature, porous media, vegetation and aeration on performance of pilot-scale vertical flow constructed wetlands. Chemical Engineering Journal, 181-182, 416-430. http://dx.doi.org/10.1016/j.cej.2011.11.108

Stottmeister, U., Wiessner, A., Kuschk, P., Kappelmeyer, U., Kastner, M., Bederski, O., Muller, R. A., \& Moormann, H. (2003). Effects of plants and microorganisms in constructed wetlands for wastewater treatment. Biotechnology Advances, 22, 93-117. http://dx.doi.org/10.1016/j.biotechadv.2003.08.010

Supakata, N., \& Chunkao, K. (2011). Thickness of moist sludge piling from community wastewater treatment through the Royal LERD technology for growing rice. Journal of Agricultural Science, 3(3), 93-100. http//dx.doi.org/10.5539/jas.v3p93

Tanji, Y., Sakai, R., Miyanaga, K., \& Unno, H. (2006). Estimation of the self-purification capacity of biofilm formed in domestic sewer pipes. Biochemical Engineering Journal, 31(1), 96-101. http://dx.doi.org/10.1016/j.bej.2006.05.021

Tateuyama, K., Egawa, H., \& Yamamoto, H. (1977). Don't waste water- weeds. Weed Resource Japan, 22, 151-156.

Thaipichitburapa, P., Meksumpun, C., \& Meksumpun, S. (2010). Province-based self-remediation efficiency of the Tha Chin river basin, Thailand. Water Science and Technology, 62, 594-602. http://dx.doi.org/10.2166/ wst.2010.293

Tripathi, B. D., \& Shukla, S. C. (1991). Biological treatment of wastewater by selected aquatic plants. Environmental Pollution, 69, 69-78.

Wahla, I. H., \& Kirkham, M. B. (2008). Heavy metal displacement in salt-water-irrigated soil during phytoremediation. Environmental Pollution, 271-283. http://dx.doi.org/10.1016/j.envpol.2007.11.020

Xia, H., \& Ma, X. (2006). Phytoremediation of ethion by water hyacinth from water. Bioresource Technology, 97, 1050-1054. http://dx.doi.org/10.1016/j.biotech.2005.04.039

Yang, Q., Tam, N. F., Wong, Y. S., Laun, T. G., Su, W. S., Lan, C. Y., Shin, P. K., \& Cheung, S. G. (2008). Potential use of mangrove as constructed wetland for municipal sewage treatment in Futian, Shenzhen, China. Marine Pollution Bulletin, 57, 735-743. http://dx.doi.org/10.1016/j.ecoleng.2009.05.017

Zaier, H., Ghnaya, T., Rejeb, B. K., Lakhdar, A., Rejeb, S., \& Jemal, F. (2010). Effects of EDTA on phytoextraction of heavy metals $(\mathrm{Zn}, \mathrm{Mn}$, and $\mathrm{Pb}$ ) from sludge-amended soil with Brassica napus. Bioresource Technology, 101(11), 3978-3983.

Zhu, Y. L., Zayed, A. M., Qian, J. H., Souza, M., \& Terry, N. (1999). Phytoaccumulation of trace elements by 
wetland plants: II. Water Hyacinth. Journal of Environmental Quality, 28(1), 339-344. http://dx.doi.org/10.2134/jeq1999.00472425002800010042x

\section{Copyrights}

Copyright for this article is retained by the author(s), with first publication rights granted to the journal.

This is an open-access article distributed under the terms and conditions of the Creative Commons Attribution license (http://creativecommons.org/licenses/by/3.0/). 